\title{
A New Mode of Cross-Border E-Business Export Logistics Based on Value Chain
}

\author{
Xiaopeng Zhao \\ City Institute of Dalian University of Technology, Dalian, China \\ Email: zxp7324@163.com
}

How to cite this paper: Zhao, X.P. (2019)

A New Mode of Cross-Border E-Business Export Logistics Based on Value Chain. Open Journal of Business and Management, 7, 1112-1119.

https://doi.org/10.4236/ojbm.2019.73076

Received: March 25, 2019

Accepted: May 5, 2019

Published: May 8, 2019

Copyright $\odot 2019$ by author(s) and Scientific Research Publishing Inc. This work is licensed under the Creative Commons Attribution International License (CC BY 4.0).

http://creativecommons.org/licenses/by/4.0/

\begin{abstract}
In order to solve the problem of cross-border e-business export logistics, in this paper, a new mode of cross-border e-business export logistics based on value chain is offered. First, the paper summed up many present modes of export logistics based on cross-border e-business, such as International postal packet, International express. And they all cannot satisfy the demands of cross-border e-business. Then, the paper cites the principle of the value chain and discusses how to apply value chain into cross-border e-business export logistics. The last part of this paper provides some suggestions.
\end{abstract}

\section{Keywords}

Value Chain, Value Chain Logistics, Cross-Border E-Business, Export Logistics, Logistics Service Integrator

\section{Introduction}

With the rapid development of e-commerce, more and more enterprises and individuals sell goods through the Internet. Especially in recent years, the global economic depression and China's emphasis on the Internet have made cross-border e-commerce become a new way of international trade, revitalized China's foreign market, and promoted the rapid, stable and sustainable development of China's economy.

The good and rapid development of cross-border e-commerce must be realized through logistics. Although China's logistics enterprises are actively involved in the logistics operation of cross-border e-commerce, the logistics is still an important limiting factor of the rapid development of cross-border e-commerce due to the limited service quality and service level, and the influence of other factors such as customs clearance policy. Especially, the export logistics of cross-border e-commerce not only tests the integration ability of logistics resources at home 
and abroad, but also directly determines the timeliness and profit space of China's goods towards the international market. In order to improve the existing modes of cross-border e-commerce export logistics in China, this paper proposes a value chain logistics model, which applies the value chain theory to the construction and operation of cross-border e-commerce export logistics system. The value chain logistics mode wants to eliminate the non-value-added operations in the cross-border e-commerce export logistics system as far as possible, and then improve the efficiency of the whole logistics system and reduce the logistics cost.

The article is organized as follows: Firstly, the paper defines the concepts related to cross-border e-commerce logistics. Then it analyzes the existing logistics mode of cross-border e-commerce export logistics, and summarizes their common problems. Finally, the paper constructs a new model of cross-border e-commerce export logistics, that is, value chain logistics model, and puts forward some suggestions for the smooth implementation of this model.

\section{Overview of Export Logistics of Cross-Border E-Commerce}

\subsection{The Concept of Cross-Border E-Commerce}

Pang, Y. [1] said cross-border e-commerce refers to a kind of international commercial activity between different trading entities (individuals or enterprises) which belong to different customs area through electronic commerce platform, online payment, and cross-border logistics to complete the transaction. Compared with the traditional trade mode, cross-border e-commerce has many advantages, such as low transaction cost, fast transaction speed and so on.

\subsection{Concept and Characteristics of Export Logistics of Cross-Border E-Commerce}

Cross-border e-commerce export logistics refers to a series of logistics processes in which logistics operators receive goods from sellers (individuals or enterprises) engaged in cross-border e-commerce business, organize domestic and foreign logistics, and send goods to foreign buyers. Its main links include domestic collection, domestic transportation and warehousing, international transport, customs clearance at home and abroad, foreign transportation and warehousing.

It can be seen that cross-border e-commerce export logistics has 3 outstanding characteristics: 1) many links and high complexity, 2) is greatly affected by political factors such as domestic and foreign customs clearance policies, 3) the global dispersion.

\section{The Existing Modes of Export Logistics of Cross-Border E-Commerce and Their Problems}

\subsection{Existing Modes of Cross-Border E-Commerce Export Logistics}

Zhang, L. [2] said there are four main export logistics modes for cross-border e-commerce at present:

1) International postal pouch 
International postal pouch is an export logistics mode of the postal system, which is mainly out of the country by means of private parcels. According to incomplete statistics, as China's cross-border e-commerce exports more goods of low value such as ornaments, clothing, handicrafts and so on, 70 percent $^{1}$ of China's cross-border e-commerce exports are delivered through the postal system especially China post in the form of parcels. Hongkong Post, Singapore Post, etc., are also common logistics methods for cross-border e-commerce sellers in China's Guangzhou-Shenzhen region.

This mode has many advantages, such as wide coverage, high efficiency of customs clearance, preferential price and so on. Meanwhile there are also some major problems, such as long transportation time, high packet loss rate and so on. Moreover, compared with the four major international express companies, China Post still has a great gap in service level and service quality.

2) International express

International express delivery mainly refers to the export logistics business of cross-border e-commerce which is operated by "giants" of international express delivery industry, such as DHL, Fedex, Ups, through border ports and customs between countries. These international express companies have a large international logistics network, advanced logistics hardware and software facilities and high-level logistics services. Therefore, compared with the domestic logistics, they have the absolute advantages of high efficiency, short transportation time and so on, but the price is relatively high.

3) Cross-border dedicated logistics

Cross-border dedicated logistics is generally to transport cargo abroad by air charter, and then send the goods to the country of destination through the cooperation company of the foreign side. Domestic logistics companies usually open a dedicated line according to the volume of cargo flow to a particular country or region, and centralize the volume of this route by means of air charter for trunk transportation, thereby reducing the cost of logistics. The price and time of the cross-border dedicated logistics are between the international express and the postal package. In addition, cross-border dedicated logistics is restricted by foreign logistics network coverage, there are some limitations in the domestic range of goods. At present, the most commonly used logistics lines in China include American line, European line, Australia line, Russian line and so on.

4) Overseas warehouse or border warehouse

Overseas warehousing services refer to one-stop logistics services provided by cross-border e-commerce platforms or logistics enterprises through self-building or leasing warehouses overseas. To be precise, overseas warehousing services should include first-trip transportation, warehousing management and local distribution. The first-trip transportation is usually carried out by sea, air or combined transport. And then, through logistics information system, overseas storage goods are remotely operated and managed in real-time. Finally, the

${ }^{1}$ NOTE: Data from China Industrial Information Network 
overseas warehouse center distributes goods to customers through the destination country's logistics system according to the e-commerce platform's order information.

Border warehouse, is similar to overseas warehouse, except that warehouse is not located within the destination country. At present, there are two kinds of border warehouses used by cross-border e-commerce in China: the first, construct or lease warehouses within our territory close to the destination country, mainly for the purpose of exporting our goods to neighbouring destination countries for cross-border e-commerce. The second, construct or lease warehouses within the borders of third countries adjacent to the destination country, mainly for the purpose of exporting our goods to non-neighbouring destination countries for cross-border e-commerce.

Both overseas warehouse and border warehouse have the advantages of fast response and low logistics cost, but there are inevitably some problems such as overstocking of goods and inadequate distribution service in foreign countries.

\subsection{Problems in the Existing Mode of Cross-Border E-Commerce Export Logistics}

The four modes of cross-border e-commerce export logistics described above, in addition to their own advantages and disadvantages, China's cross-border e-commerce export logistics also has the following common problems:

1) Many logistics links, long delivery cycle and high logistics cost

Compared with domestic e-commerce logistics, cross-border e-commerce export logistics is restricted by a variety of factors, such as customs clearance policy, domestic and foreign logistics standards and so on, resulting in longer logistics operation cycle and higher cost, which seriously affect the satisfaction of foreign customers, and restrict the development of China's export cross-border e-commerce.

2) It is very difficult to return and exchange goods

Like domestic online shoppers, cross-border e-commerce consumers may want to return and exchange goods because they are not satisfied with the goods received. However, as the cross-border e-commerce export logistics cycle is so long, the return and exchange cargo flow is so small, and the logistics cost is so high, that it is almost impossible to return and exchange goods. This also greatly reduces the satisfaction and purchase willingness of foreign customers of cross-border e-commerce.

3) Shen et al. [3] said that goods logistics information tracking is not timely after leaving China

Although our goods can be tracked and located at any time through the logistics information system in China, after leaving China the logistics information cannot be tracked in time due to various factors, such as the inconsistent level of information, the non-sharing of information interfaces and the like between countries. 


\section{A New Mode of Cross-Border E-Commerce Export Logistics Based on Value Chain Perspective}

\subsection{Value Chain and Value Chain Management}

Value chain theory was first presented in the book "competitive advantage" in 1985 by Michael Porter, professor and expert in Strategic Management, Harvard University, USA. Michael E. Porter [4] divides activities that add value inside and outside the enterprise into basic and supportive activities. Basic activities include enterprise production, sales, logistics, after-sales service. Support activities include personnel, finance, planning, research and development, procurement, etc. Basic activities and supportive activities constitute the value chain of the enterprise. The advantage of an enterprise can be derived not only from the adjustment of the market scope involved in value activities, but also from the optimal benefits brought about by the coordination or sharing of value chains between enterprises. Efficient value chain design, information sharing among value chain members, good coordination between inventory visibility and production, will reduce inventory level, and logistics operations will be more effective.

The concept of value chain management originated from the view that enterprises should look at the operating effect from the point of view of total cost, rather than pursuing the optimization of purchasing, production, distribution and other functions one-sidedly. The purpose of value chain management is to achieve the best business performance by coordinating each link of the value chain, so as to enhance the business performance of the whole enterprise. Efficient value chain design, information sharing among value chain members, good coordination between inventory visibility and production, can effectively reduce inventory level, improve logistics efficiency and improve order fulfillment rate and other key business functions. If each link of the value chain only improves itself alone, rather than integrating its goals and activities with other sectors, the whole chain will show unsatisfactory performance. In a word, value chain management is a strategy based on co-operation, which connects business operations across enterprises in order to achieve the common goal of the whole chain.

\subsection{Core Idea of Logistics Mode Based on Value Chain}

Zhou et al. [5] said that applying the idea of value chain to the field of logistics means that in the logistics process of the core enterprises and the upstream and downstream enterprises of the supply chain, they are connected to each other in order to form a network with intrinsic value-benefit relationship. The logistics value chain is the essence of the internal interest relationship of the supply chain, and is the motive force of the supply chain. The supply chain emphasizes the flow process of goods in the logistics operation, and the value chain not only attaches importance to the flow process of goods, but also attaches importance to the flow process of capital and value in the logistics operation. It can be concluded that under the condition of supply chain, logistics is oriented to optimize the integration of physical resources and integrate them into the integrated 
management. Under the condition of the value chain, the logistics is oriented to the overall operation of the value strategy, and from the ultimate level of logistics value to achieve the optimal logistics efficiency with the idea of taking the overall situation. Therefore, each link in the value chain with logistics participation constitutes a logistics value chain. From the point of view of value, the logistics value chain is constructed by the third-party logistics enterprises co-producers, channel merchants and customers to promote the value-added value of the value-chain alliance through effective logistics operation, and to enhance the competitiveness of the alliance enterprises.

The export logistics model of cross-border e-commerce based on value chain, introducing the management method of value chain into cross-border e-commerce export logistics activities, carrying out value creation activities, and providing valuable products or services to customers. Its task is to check the cost and performance of each value-creating activity, to integrate each resource element and link in the logistics value chain and to seek improvement, so as to maximize the value. This logistics model can not only make foreign customers of cross-border e-commerce get the organic sum of value created by the activities of value chain link from the consumption of final products, but also promote the enterprises of value chain alliance to improve their core competitiveness and operating efficiency.

\subsection{The Thought of Constructing a New Mode of Cross-Border E-Commerce Export Logistics Based on the View of Value Chain}

In view of the advantages and disadvantages of the existing export logistics modes of cross-border e-commerce in China, there are many common problems, such as the long cycle of logistics operation, the high cost, the difficulty of returning and exchanging goods, and so on. This paper applies the value chain theory to the logistics field, and puts forward the new mode of the cross-border e-commerce export logistics, that is, the mode of value chain logistics.

$\mathrm{Du}$ et al. [6] said that value chain logistics mode is an innovation of supply chain management mode, which aims to meet the individual logistics needs of customers, and links each value-added logistics operation into a complete value chain. The implementer of value chain logistics mode must be a logistics service integrator, who can integrate logistics resources according to the specific needs of customers, design and organize the whole logistics operation scheme, and make each component of the value chain join seamlessly. When customers have logistics needs, logistics service integrator can design logistics solutions for them, and select the appropriate members to make up the value chain by assessing the logistics resources and level of logistics operation owned by themselves and member enterprises. Work together to complete the whole logistics program. Therefore, in the value chain logistics mode, the logistics service integrator undertakes the management function of integrating logistics resources, planning, organizing, directing and controlling the whole logistics operation. It can not 
only design the corresponding level of logistics operation scheme according to the customer's demand and cost budget, but also select the best member to make up the value chain by effectively integrating logistic resources. And then reduce the logistics cost of the whole system and even the whole society.

Under the model of value chain logistics, the operation principle of cross-border e-commerce export logistics is shown in Figure 1: 1) When the domestic cross-border e-commerce receives foreign customer order information, it will inform the logistics service integrator of the order details, and the logistics service integrator will organize the shipment. 2) The logistics service integrator makes logistics operation plans according to the information on the order, such as the attributes of goods, volume and exporting countries, and select the appropriate logistics enterprises to form the value chain. 3) According to the established logistics plan, the goods will be collected from each supplier through domestic transportation to a domestic logistics center. The goods that need to be cleared are ready for customs clearance in advance. Then choose the appropriate international mode of transport according to the logistics period required by foreign customers to transport the goods to the destination country. 4) After the goods are transported to the destination country, the destination country cooperation enterprise is arranged to complete the customs clearance and the final one-kilometer distribution, or the large-volume goods are stored in the overseas warehouse, and then carry out the last kilometer distribution according to the instruction from foreign customers. It can be seen that it is necessary for logistics service integrator to build or rent local warehouses at suitable locations outside the country according to the actual logistics needs of customers. 5) When foreign customers need to return and exchange goods, through the above logistics channels to achieve the reverse logistics.

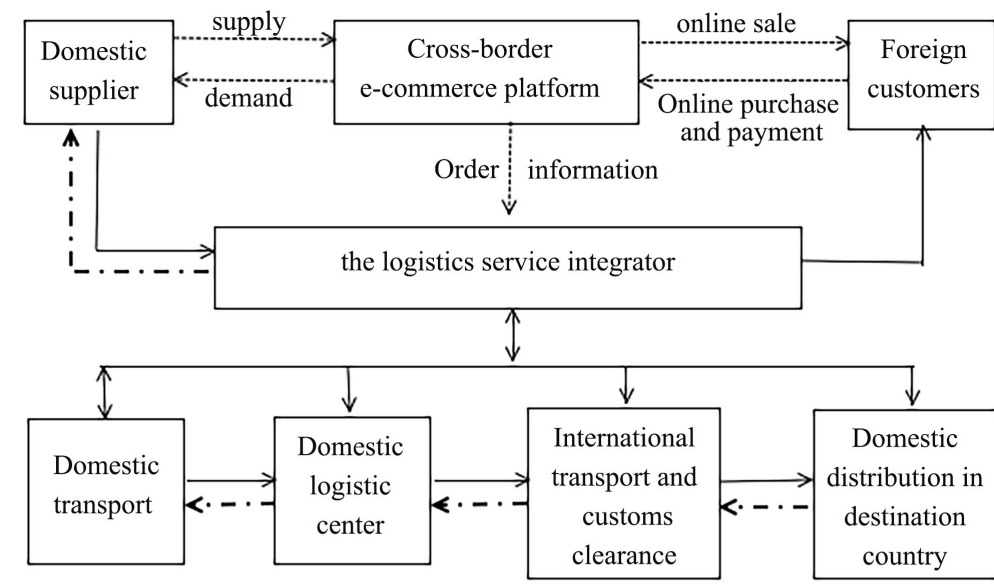

NOTE:

1. $\longrightarrow$ Means cargo flow; $\longleftrightarrow$ Means Forward and reverse cargo flow;

2. $-\cdots-\cdots \rightarrow$ Means information flow;...$--\rightarrow$ Means Reverse cargo flow.

Figure 1. Export Logistics process of cross-border e-commerce under the Mode of value chain logistics. 


\section{Suggestions on the Implementation of the New Mode of Export Logistics for Cross-Border E-Commerce}

In order to ensure the smooth implementation of the value chain logistics model and improve the overall benefits of the cross-border e-commerce export logistics system, this paper gives the following suggestions:

1) Logistics service integrator should have a good understanding of value chain and supply chain management principles and be able to apply this principle skillfully to cross-border e-commerce export logistics organizations.

2) Logistics service integrator should have the ability to refine and classify different service levels correspond to different logistics service prices, so that different levels of cross-border e-commerce according to the value of their own goods make the corresponding choice of logistics services.

3) Improve the standardization of China's logistics, which will greatly enhance the efficiency of cross-border e-commerce export logistics.

4) Train cross-border e-commerce logistics complex talents.

5) Give full play to the role of the government, encourage more enterprises to pass the certification of WCO, develop into "AEOS", and improve the efficiency of customs clearance.

\section{Conflicts of Interest}

The author declares no conflicts of interest regarding the publication of this paper.

\section{References}

[1] Pang, Y. (2015) Research on International Logistics Model in Cross-Border E-Commerce Environment. Chinese Journal of Circulation Economy, 10, 15-20.

[2] Zhang, L. (2016) Research on the Mode of Cross-Border E-Commerce Logistics in China. E-Business Journal, 12, 9-10.

[3] Shen, D.Y., Huang, J.L. and He, S.Q. (2015) Research on the Model of Cross-Border E-Commerce Logistics in China. Journal of Price, 8, 39-42.

[4] Porter, M.E. (2014) Competitive Advantage: Creating and Sustaining Superior Performance. Translated by Chen, L.F., Zhong Xin Publishing House, Wuhan.

[5] Zhou, X.J. and Zhang, Q.N. (2010) Study on the Formation and Formation Mechanism of Logistics Value Chain Based on the Logistics Mode of Home Appliances. Chinese Journal of Circulation Economy, 3, 26-29.

[6] Du, S.P., Lu, Y. and Zhang, Z.Y. (2009) Value Chain of Logistics Industry and Its Operating Mechanism. Journal of Commercial Research, 8, 154-156. 